\title{
PENERAPAN SISTEM PRESENSI MOBILE DENGAN MENGGUNAKAN SENSOR GPS (KLINIK PRATAMA X DI JEMBER)
}

\author{
Ely Mulyadi ${ }^{1}$, Andis Trihariprasetya ${ }^{2}$, I Gede Wiryawan ${ }^{3}$ \\ 1,2,3 Jurusan Teknologi Informasi, Politeknik Negeri Jember \\ Jember, Indonesia
}

e-mail: elymulyadi@polije.com ${ }^{1}$, andissetya@gmail.com², wiryawan@polije.ac.id ${ }^{3}$

\begin{abstract}
Abstrak
Perangkat dengan sensor sidik jari yang digunakan sebagai perangkat khusus untuk menangani presensi sangat rentan mengalami kerusakan dan susah untuk dikonfigurasikan di saat awal penggunaannya. Dengan penelitian ini, harapannya diperoleh suatu perangkat alternatif yang bisa menggantikan perangkat khusus tersebut. Dalam penelitian ini dikembangkan sistem presensi pada perangkat mobile yang telah dimiliki oleh mayoritas orang dengan memanfaatkan sensor Global Positioning System. Metode yang digunakan dalam mengembangkan penelitian ini adalah metode pengembangan perangkat lunak scrum. Sistem presensi ini diterapkan pada salah satu klinik kesehatan di Jember. Implementasi sistem presensi yang dikembangkan secara umum dapat berjalan dengan baik dan dibuktikan dengan hasil pengujian dengan metode Black box dan kuisioner sederhana untuk pengguna sistem. Dari hasil kuisioner didapatkan nilai rata-rata 4,36 . Hal yang masih perlu menjadi pertimbangan untuk pengembangan kedepannya adalah kecepatan respon dari sistem presensi ini.
\end{abstract}

Kata kunci: Sistem presensi, Mobile, Global Positioning System

\begin{abstract}
Devices with fingerprint sensors, commonly used as special devices to handle attendance, are very vulnerable to damage and difficult to configure at the initial use. With this research, it is hoped that an alternative device can be replaced. In this study, a presence system was developed on the mobile devices that had been owned by the majority of people by utilizing the Global Positioning System sensor. The method used in developing this research is Scrum. This presence system is implemented in a health clinic in Jember. Implementation of the present system that was developed in general can run well and it is evidenced by the results of testing with the black box method and a simple questionnaire for system users. The results of the questionnaire obtained an average value of 4.36. A thing that still needs to be considered for future development is the speed of response from this present system.
\end{abstract}

Keywords : Present system, Mobile, Global Positioning System

\section{PENDAHULUAN}

Presensi karyawan mencerminkan kinerja dari karyawan suatu perusahaan. Saat ini telah banyak tersedia perangkat yang menggunakan identifikasi sidik jari untuk membuktikan bahwa karyawan tersebut telah hadir di kantor. Akan tetapi perangkat yang digunakan sebagai perangkat khusus menangani presensi tersebut rentan mengalami kerusakan dan susah untuk dikonfigurasikan di saat awal penggunaannya. Di samping itu, perangkat lunak yang menunjang fungsionalitas biasanya tidak sesuai dengan kebutuhan perusahaan. Efektifitas dari pemanfaatan perangkat presensi dengan identifikasi sidik jari ini juga masih memiliki celah untuk dicurangi, yaitu dengan hanya datang untuk kemudian ditinggal pergi keluar kantor lagi.

Seiring berjalannya waktu, teknologi lain yang lebih canggih telah diterapkan untuk menangani permasalahan dari 
perangkat presensi karyawan yang masih menggunakan identifikasi sidik jari tersebut. Salah satunya adalah dengan menerapkan teknologi Radio Frequency Identification (RFID) [1] [2]. Namun teknologi tersebut masih memiliki beberapa kekurangan, yang salah satunya ialah tidak bisa melakukan validasi identitas asli dari pemegang tagcard yang memancarkan frekuensi radio [1].

Pengguna perangkat mobile, seperti smartphone berbasis Android, mengalami peningkatan yang sangat masif sekali. Saat ini perangkat mobile biasanya telah dilengkapi dengan sensor penerima Global Positioning System (GPS) [3]. Teknologi sensor yang tertanam pada perangkat mobile tersebut dapat dimaanfaatkan sebagai perangkat presensi karyawan. Hanya dengan mendapatkan data lokasi dari perangkat mobile yang dimiliki oleh karyawan, sistem telah dapat menentukan status presensi dari karyawan tersebut.

Sistem presensi dengan menggunakan teknologi sensor penerima GPS pada perangkat mobile telah banyak diimplementasikan di berbagai sektor. Salah satunya sistem presensi tersebut diterapkan di bidang pendidikan dengan objek karyawan dan dosen DPK pada perguruan tinggi [4] [5]. Awalnya sistem melakukan pelacakan lokasi pengguna, dimana sebelumnya telah dibedakan antara area kampus dengan area non-kampus. Jadi apabila lokasi pengguna berada di area kampus, maka sistem akan mendeteksi perangkat yang telah check-in [4].

Berikutnya penelitian yang dilakukan terhadap pegawai dari perusahaan listrik di Malang dengan basecamp Mojokerto. Penelitian ini menggunakan metode Lock GPS, sehingga dapat menghitung posisi 2D (latitude dan longitude) dan jalur pergerakan dengan mengunci sinyal dari tiga satelit. Apabila GPS Reciever menerima empat atau lebih satelit, maka dapat dihitung posisi 3D (latitude, longitude dan altitude) [6]. Terakhir, penelitian yang menerapkan sistem presensi untuk penyiar radio swasta di Semarang [7]. Metode Haversine dimplementasikan untuk melakukan perhitungan jarak antara titik lokasi studio dengan perangkat mobile yang melakukan proses presensi. Selain itu juga digunakan metode Geofence sebagai penanda area akses yang terlihat pada Google Maps.

Beberapa permasalahan yang diuraikan secara singkat sebelumnya melatarbelakangi penelitian dalam diimplementasikan sistem presensi berbasis lokasi menggunakan perangkat mobile ini. Namun yang membedakan sistem ini dengan sistem presensi sebelumnya adalah sistem presensi ini diterapkan di bidang kesehatan. Sistem presensi yang digunakan dalam bidang kesehatan berbeda sekali dengan sistem presensi pada umumnya, dimana pada bidang kesehatan harus siap sedia 24 jam. Sistem presensi ini terintegrasi dengan sistem informasi manajemen klinik yang telah dikembangkan dan dievaluasi sebelumnya [8], sehingga dalam pemanfaatan sistem presensi ini sangat mendukung manajemen dari klinik kesehatan yang menggunakan sistem tersebut.

\section{Tinjauan Pustaka}

Sebelum penelitian ini, telah banyak penelitian yang mengangkat topik mengenai sistem presensi berbasis lokasi. Salah satunya otomatisasi sistem presensi menggunakan Global Positioning System (GPS) untuk pegawai pada suatu kampus [4]. Permasalahan yang menjadi latar belakang dilakukannya penelitian otomatisasi ini adalah kerentanan perangkat presensi biometrik (fingerprint) terhadap distorsi yang disebabkan oleh kotoran dan juga kecurangan dengan menggunakan jari palsu. Sistem yang tertanam pada perangkat presensi tersebut juga akan berjalan lambat jika digunakan dalam jangka waktu panjang, karena sensor yang berfungsi untuk mendeteksi karakteristik pegawai akan mengalami penyusutan pemakaian seiring berjalannya waktu.

Penelitian ini menggunakan Location Based Service untuk melacak informasi spasial pegawai di dalam area kampus, dimana sistem akan membatasi cakupan area kampus dengan area non-kampus berupa titik koordinat yang diperoleh dari Google Map API. Jika pegawai berada pada area kampus, maka pegawai dinyatakan 
check-in dan mendapatkan notifikasi telah melakukan presensi. Namun apabila pegawai berada di luar area kampus, maka sistem akan mengirimkan notifikasi bahwa perangkat telah keluar dari area kampus.

Penelitian selanjutnya adalah implementasi dari aplikasi absensi dengan menggunakan metode Lock GPS pada sebuah perusahaan listrik di Kota Malang, namun memiliki basecamp di Kota Mojokerto [6]. Permasalahan yang diangkat dalam penelitian ini adalah jarak antara kantor dengan gardu induk yang sangat jauh sekali. Penelitian ini memanfaatkan teknologi smartphone Android yang dibekali fitur GPS dan WiFi sebagai alat untuk melakukan presensi pegawai langsung dari kantor atau pun gardu induk.

Perancangan aplikasi absensi ini adalah berupa sistem flow untuk menunjukan jalannya program aplikasi secara garis besar, selain itu juga digunakan Data Flow Diagram (DFD) dalam proses perancangan ini. Sedangkan pada perancangan basis data, aplikasi absensi ini menggunakan entity relationship diagram (ERD). Dalam pengujiannya, penelitian ini berfokus pada pengujian aplikasi frontend (client service android) dan pelaporan atau report dari aplikasi backend (web service). Hasilnya, aplikasi absensi yang dikembangkan cukup mampu berjalan dengan baik walaupun masih banyak kekurangan.

Penelitian tentang sistem presensi berikutnya adalah penerapan sistem presensi khusus untuk Dosen Dipekerjakan (DPK) pada sebuah perguruan tinggi swasta [5]. Banyaknya kekurangan dan ketidakefektifan dari pencatatan presensi dengan menggunakan kartu dan fingerprint menjadi permasalahan yang akan dipecahkan dalam penelitian ini. Dalam implementasinya, administrator dari sistem presensi ini memiliki otoritas untuk melakukan verifikasi dari informasi presensi. Pada sistem presensi di Android terdapat tampilan pengambilan foto untuk melakukan pencatatan presensi serta di posisi atas terdapat tulisan yang menunjukan lokasi.

Perancangan sistem presensi ini adalah dengan memodelkannya ke dalam diagram alir (flowchart). Dari implementasi dan pengujian uji coba fitur, sistem presensi digunakan untuk melakukan presensi Dosen DPK dengan melihat lokasinya dapat berjalan sesuai dengan yang diharapkan. Dengan adanya sistem presensi ini, keamanan informasi presensi dari kecurangan dalam pencatatan presensi sudah berjalan dengan optimal.

Penelitian yang terkait dengan sistem presensi selanjutnya adalah sistem presensi menggunakan Global Positioning System berbasis Android yang diterapkan untuk penyiar di Radio Thomson Semarang. Perencanaan pada penelitian ini menggunakan metode Haversine untuk menghitung jarak antara titik posisi kantor ke titik lokasi posisi penyiar. Sistem presensi ini menerapkan metode Geofence sebagai indikasi radius dimana penyiar dapat melakukan proses presensi. Hasilnya menunjukan perbedaan perhitungan jarak antara sistem dengan perhitungan jarak secara manual sebesar $\pm 0,2$ meter.

\section{METODE}

$\begin{array}{lcr}\text { Sebelum } & \text { memulai } & \text { tahap } \\ \text { pengembangannya, } & \text { terlebih } & \text { dahulu } \\ \text { dilakukan pemodelan sistem } & \text { dengan }\end{array}$ menggunakan Unified Modeling Language (UML). Gambar 1 menunjukan salah satu pemodelan dari sistem presensi yang dikembangkan dalam penelitian ini, yaitu dengan Activity Diagram.

Dari activity diagram tersebut, dapat dijelaskan secara singkat bahwa setelah pegawai berhasil login terdapat empat pilihan aktivitas yang dapat dilakukan, yaitu melakukan absen datang, absen pulang, absen lembur, dan perizinan. Pada sistem presensi terdapat aktivitas pendeteksian lokasi, setelah pegawai melakukan absen datang, pulang dan lembur. Jika lokasi sesuai dengan titik koordinat yang telah ditentukan, maka sistem akan menyimpan data presensi dari pegawai tersebut. Khusus untuk perizinan, dibutuhkan inputan tanggal dan alasan izin sebelum data izin dari pegawai dapat tercatat ke dalam sistem.

Sedangkan untuk metode yang digunakan dalam mengembangkan sistem 
presensi ini adalah metode Scrum. Metode Scrum adalah metode rekayasa perangkat lunak dengan menggunakan prinsip pendekatan Agile yang bertumpu pada kekuatan kolaborasi tim, incremental product, dan proses iterasi untuk mewujudkan hasil akhir. Metode Scrum berfokus kepada manajemen proyek yang memberikan kerangka kerja bagaimana mengelola suatu proyek berbasis Agile. Metode ini memberikan pola "ceremony" apa saja yang harus dijalankan dan "role" apa saja yang ada termasuk tugas yang harus diperankan [9].

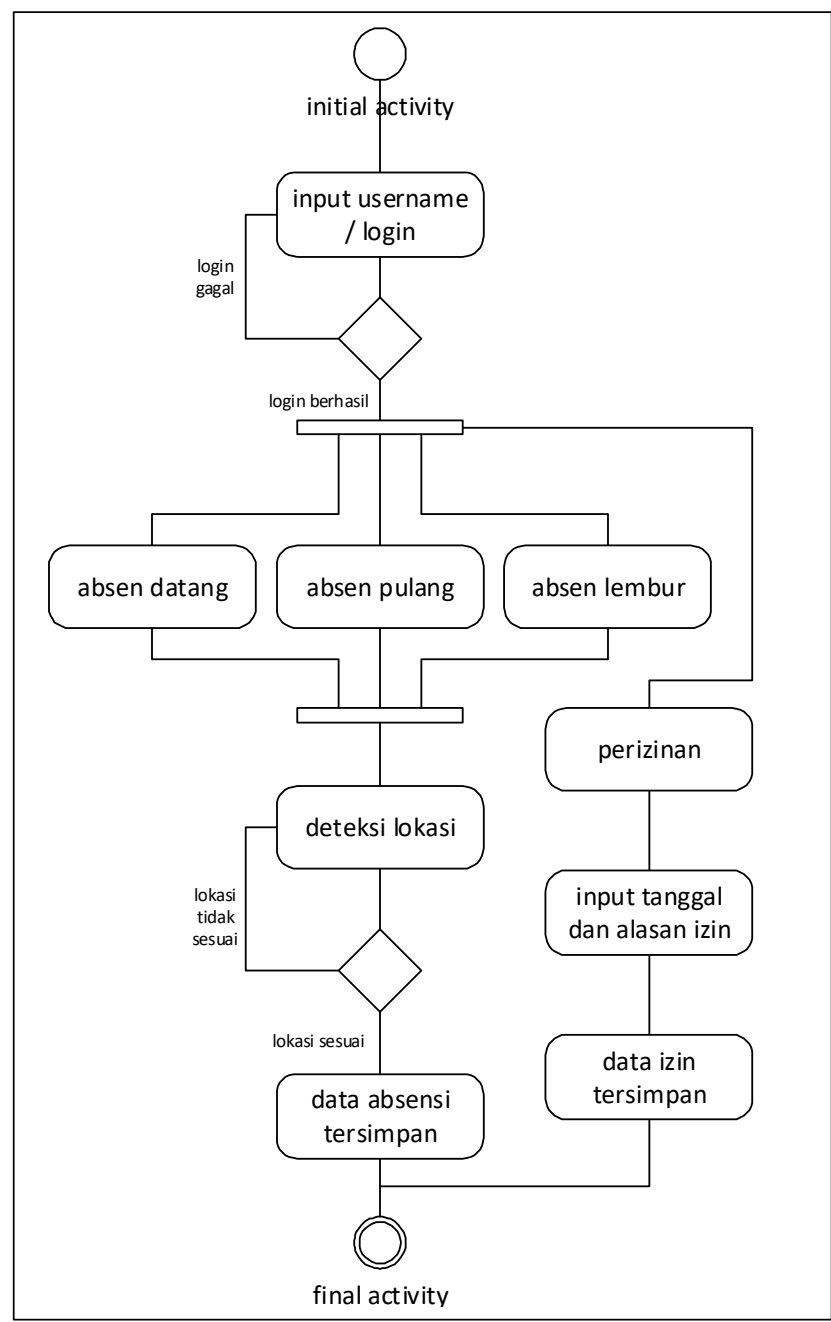

Gambar 1. Activity Diagram dari Sistem Presensi

Terdapat 2 metode yang digunakan untuk pengujian aplikasi ini. Metode pertama adalah metode pengujian fungsionalitas "Black box". Metode pengujian pertama ini dilakukan berdasarkan spesifikasi kebutuhan dan tidak ada pemeriksaan kode. Alasan digunakannya metode pengujian ini adalah dikarenakan metode Black box ini memainkan peran yang signifikan dalam pengujian perangkat lunak, dan membantu validasi keseluruhan fungsionalitas [10].

Pengujian berikutnya adalah dengan menggunakan kuisioner sederhana yang diberikan kepada pengguna aplikasi ini. Data pengujian ini diperoleh dari para pegawai salah satu klinik pratama di kota Jember. Jadi pengujian ini juga dapat dikatakan sebagai pengujian User Acceptance. Data kuisioner yang diambil tersebut adalah berupa pertanyaan mengenai beberapa aspek atau kriteria yang sangat berhubungan dengan pengguna dari aplikasi ini [11]. Aspek tersebut diantaranya adalah sebagai berikut.

1) Konsep aplikasi

2) Kegunaan aplikasi

3) Model bisnis aplikasi

4) Tingkat akurasi aplikasi

5) Kecepatan respon aplikasi

6) Keramahan penggunaan aplikasi

\section{HASIL DAN PEMBAHASAN}

Hasil dari penelitian yang telah dilakukan ini adalah aplikasi berupa sistem presensi yang dipasang pada perangkat mobile berbasis Android. Sistem presensi ini diterapkan pada salah satu klinik pratama di kota Jember. Masukan dari aplikasi ini adalah berupa jenis presensi dan pergantian waktu presensi (shift). Jenis presensi yang diterima sebagai masukan pada sistem presensi ini antara lain presensi datang, presensi pulang, dan presensi lembur. Pergantian waktu pada sistem presensi ini dibagi menjadi tiga, yaitu shift pagi, shift siang, dan shift malam.

Tampilan awal ketika pertama kali menjalankan aplikasi ini adalah tampilan login untuk seluruh pegawai dengan menggunakan username berupa nomor identitas pegawai. Pegawai hanya dapat melakukan login sebanyak satu kali. Jika login berhasil dilakukan, maka aplikasi otomatis akan langsung menyimpan data pegawai yang sudah dimasukan dan 
pegawai tersebut tidak akan dapat logout dari aplikasi. Hal ini bertujuan untuk menghindari kecurangan para pegawai dalam penggunaan perangkat mobile yang sama untuk presensi rekannya.

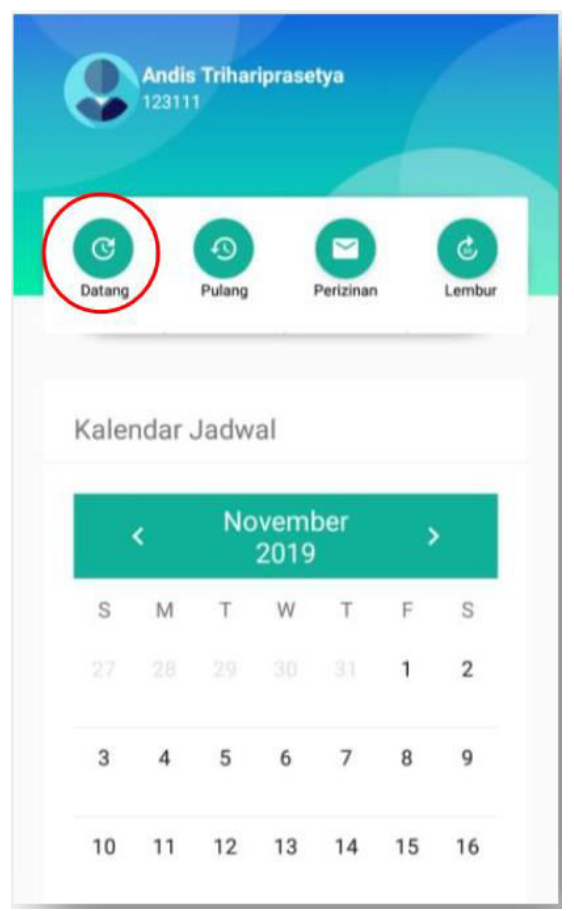

Gambar 2. Tampilan Utama

Tampilan utama dari aplikasi ini ditunjukan pada Gambar 2 di atas. Bagian atas dari tampilan utama terdapat nama pegawai dan nomor identitas dari pegawai tersebut. Menu jenis presensi terdapat pada bagian tengah dari tampilan utama, yang diantaranya adalah presensi datang, pulang, dan lembur. Selain itu juga terdapat menu perizinan, menu tersebut digunakan pegawai untuk mengajukan permohonan izin. Bagian paling bawah dari tampilan utama aplikasi ini menunjukan kalender. Setelah memilih menu jenis presensi, pegawai menginputkan shift dari presensi. Selanjutnya pegawai menyentuh tombol masuk seperti yang ditunjukan pada Gambar 3 di bawah ini.

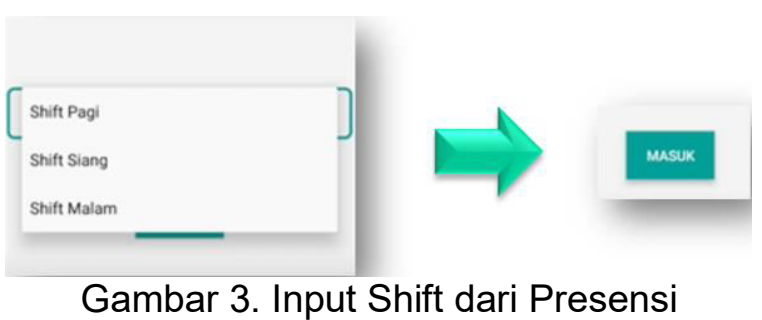

Berikutnya aplikasi akan melakukan pendeteksian lokasi dari salah satu klinik pratama di kota Jember. Pendeteksian lokasi tersebut dengan menggunakan sensor Global Positioning System yang telah tertanam di hampir seluruh perangkat mobile saat ini. Pada tampilan pendeteksian lokasi ini terdapat peta di sekitar lokasi (titik koordinat) perangkat mobile yang digunakan. Namun apabila titik koordinat dari perangkat mobile masih kurang tepat, maka pegawai hanya perlu menyentuh ikon "Lokasiku" di bagian tengah bawah dari gambar peta.

Seperti yang ditunjukan pada gambar 4, lokasi perangkat mobile yang tidak sesuai dengan lokasi salah satu klinik pratama di kota Jember akan membuat tombol untuk mencatat status presensi menjadi nonaktif / disabled. Sedangkan jika lokasi perangkat mobile sesuai dengan lokasi salah satu klinik pratama di kota Jember, maka tombol akan aktif / enabled dan dapat digunakan untuk mencatat satus presensi. Data status presensi akan otomatis tersimpan setelah tombol tersebut disentuh. 


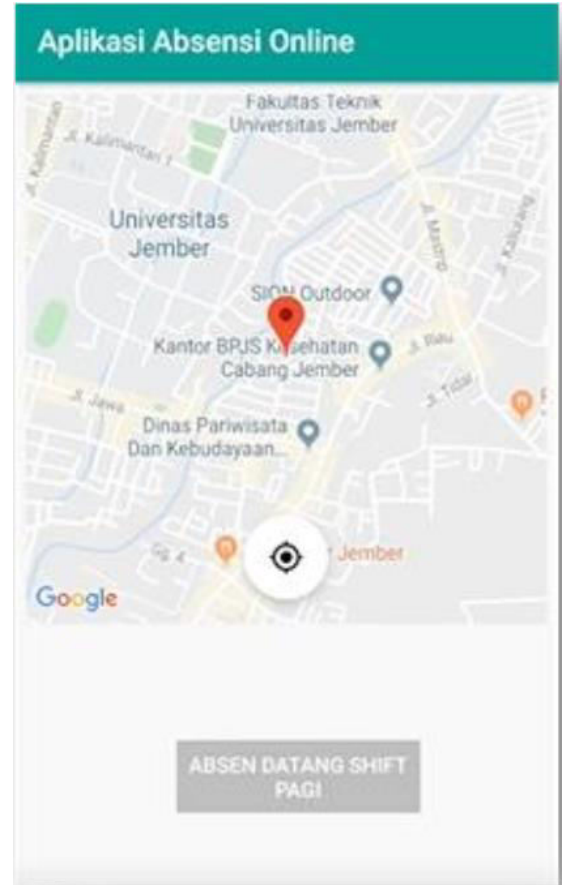

Gambar 4. Tampilan Pendeteksian Lokasi pada Menu Absen Datang

Berikutnya aplikasi akan melakukan pendeteksian lokasi dari salah satu klinik pratama di kota Jember. Pendeteksian lokasi tersebut dengan menggunakan sensor Global Positioning System yang telah tertanam di hampir seluruh perangkat mobile saat ini. Pada tampilan pendeteksian lokasi ini terdapat peta di sekitar lokasi (titik koordinat) perangkat mobile yang digunakan. Namun apabila titik koordinat dari perangkat mobile masih kurang tepat, maka pegawai hanya perlu menyentuh ikon "Lokasiku" di bagian tengah bawah dari gambar peta.

Seperti yang ditunjukan pada gambar 4, lokasi perangkat mobile yang tidak sesuai dengan lokasi salah satu klinik pratama di kota Jember akan membuat tombol untuk mencatat status presensi menjadi nonaktif / disabled. Sedangkan jika lokasi perangkat mobile sesuai dengan lokasi salah satu klinik pratama di kota Jember, maka tombol akan aktif / enabled dan dapat digunakan untuk mencatat satus presensi. Data status presensi akan otomatis tersimpan setelah tombol tersebut disentuh.

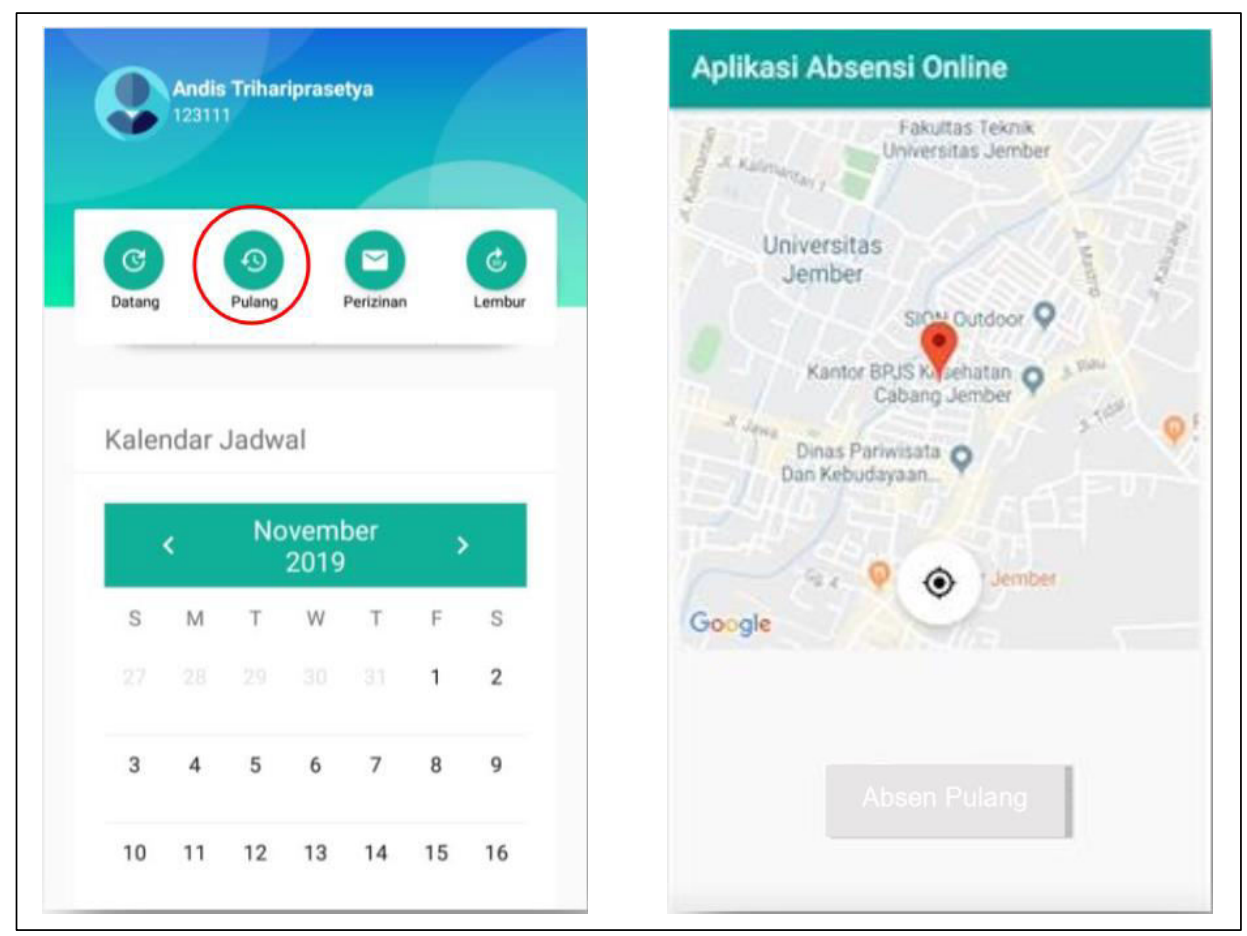

Gambar 5. Tampilan Menu Absen Pulang dan Pendeteksian Lokasinya 
Pada saat jam kerja telah berakhir maka pegawai dapat memilih menu presensi pulang. Berbeda dengan menu presensi datang, aplikasi tidak membutuhkan inputan shift pada menu presensi pulang. Setelah memilih menu presensi pulang, aplikasi akan langsung menampilkan tampilan pendeteksian lokasi lagi. Seperti tampilan pendeteksian lokasi pada menu presensi datang, tampilan pendeteksian pada menu presensi pulang ini juga menampilkan peta di sekitar lokasi perangkat yang digunakan.

Gambar 5 menunjukan setelah pegawai memilih menu presensi pulang, aplikasi menampilkan tampilan pendeteksian lokasi. Jika lokasi dari perangkat mobile tidak sesuai dengan lokasi salah satu klinik pratama di kota Jember, maka tombol untuk mencatat status presensi menjadi nonaktif. Tombol pencatatan presensi pulang akan aktif ketika lokasi perangkat yang digunakan sesuai dengan lokasi salah satu klinik pratama di kota Jember.

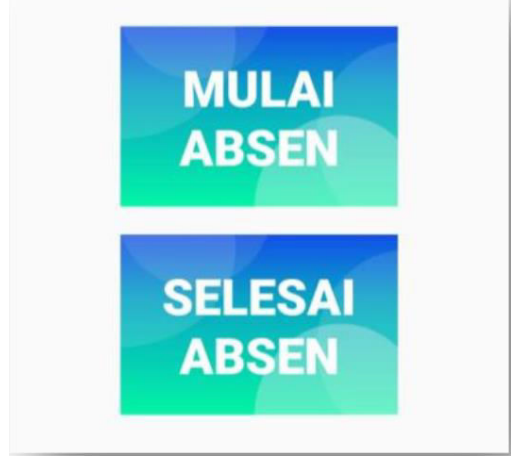

\section{Gambar 6. Tampilan Menu Presensi Lembur}

Selain fitur pencatatan presensi datang dan pulang, aplikasi ini juga terdapat fitur pencatatan presensi pada saat lembur. Untuk memulai lembur, pegawai harus memilih menu presensi lembur. Kemudian aplikasi akan menampilkan tampilan dengan dua tombol, seperti yang ditunjukan Gambar 6. Pada tampilan tersebut, awalnya pegawai harus memilih tombol mulai absen. Setelah memilih tombol mulai absen, aplikasi kembali menampilkan tampilan pendeteksian lokasi seperti pada menu presensi datang dan pulang. Namun yang berbeda dari tampilan pendeteksian lokasi ini adalah tombol yang ada di bagian bawah, tombol tersebut adalah tombol absen lembur. Jika akan mengakhiri presensi lembur, maka pegawai harus memilih tombol selesai absen. Fitur terakhir pada aplikasi ini adalah pencatatan perizinan pegawai. Setelah pegawai memilih menu presensi perizinan, aplikasi meminta inputan berupa tanggal dan alasan izin.

Dari pembahasan mengenai sistem presensi sebelumnya, seluruh fungsionalitas dari aplikasi dapat berjalan dengan baik. Hal tersebut dapat dibuktikan dari hasil pengujian fungsionalitas yang dilakukan dengan menggunakan metode Black box. Tabel 1 di bawah ini menunjukan hasil dari pengujian dengan metode Black box.

Tabel 1. Hasil Pengujian Black box

\begin{tabular}{|c|c|c|c|c|}
\hline No & Skenario Pengujian & Test Case & $\begin{array}{l}\text { Hasil yang } \\
\text { Diharapkan }\end{array}$ & $\begin{array}{c}\text { Hasil } \\
\text { Pengujian }\end{array}$ \\
\hline \multicolumn{5}{|c|}{ Activity Login } \\
\hline 1. & $\begin{array}{l}\text { User login menggunakan username } \\
\text { dengan NIP benar }\end{array}$ & $\begin{array}{l}\text { username: } \\
123111\end{array}$ & $\begin{array}{l}\text { Login berhasil dan } \\
\text { diarahkan ke Menu }\end{array}$ & sesuai \\
\hline 2. & $\begin{array}{l}\text { User login menggunakan username } \\
\text { dengan NIP salah }\end{array}$ & $\begin{array}{l}\text { username: } \\
000000\end{array}$ & $\begin{array}{l}\text { Login gagal dan } \\
\text { tampil pemberitahuan } \\
\text { "username tidak } \\
\text { ditemukan" }\end{array}$ & sesuai \\
\hline \multicolumn{5}{|c|}{ Activity Menu Utama } \\
\hline 1. & User melakukan presensi datang & Menu & Menampilkan pilihan & sesuai \\
\hline
\end{tabular}


dengan memilih menu datang

2. User melakukan presensi pulang dengan memilih menu pulang

3. User melakukan presensi lembur dengan memilih menu lembur

4. User melakukan izin dengan memilih menu perizinan

Activity Menu Datang

1. User melakukan presensi datang dengan memilih shift masuk kerja pagi

\begin{tabular}{c|l}
\hline No & \multicolumn{1}{|c}{ Skenario Pengujian } \\
\hline 2. & $\begin{array}{l}\text { User melakukan presensi datang } \\
\text { dengan memilih shift masuk kerja } \\
\text { siang }\end{array}$ \\
3. & $\begin{array}{l}\text { User melakukan presensi datang } \\
\text { dengan memilih shift masuk kerja } \\
\text { malam }\end{array}$
\end{tabular}

Activity Menu Lembur

1. User melakukan presensi lembur dengan memilih mulai lembur

2. User melakukan presensi lembur dengan memilih selesai lembur

Activity Menu Perizinan

1. User memilih tanggal izin

2. User memasukan data detail alasan izin dan mengirimkannya

Activity Deteksi Lokasi Perangkat

1. Sistem mendeteksi lokasi dari perangkat dengan lokasi di dalam klinik ( $<5$ meter)

2. Sistem mendeteksi lokasi dari perangkat dengan lokasi di luar klinik ( $>5$ meter)

\begin{tabular}{|l|l|r} 
datang & shift masuk kerja & \\
Menu pulang & $\begin{array}{l}\text { Menampilkan deteksi } \\
\text { lokasi perangkat }\end{array}$ & sesuai \\
Menu & $\begin{array}{l}\text { Menampilkan pilihan } \\
\text { mulai lembur dan }\end{array}$ & sesuai \\
lembur & $\begin{array}{l}\text { selesai lembur } \\
\text { Menumpilkan pilihan } \\
\text { perizinan }\end{array}$ & $\begin{array}{l}\text { Menamal } \\
\text { tanggal izin }\end{array}$
\end{tabular}

\begin{tabular}{|c|c|c|}
\hline Shift pagi & $\begin{array}{l}\text { Menampilkan deteksi } \\
\text { lokasi perangkat }\end{array}$ & sesuai \\
\hline Test Case & $\begin{array}{l}\text { Hasil yang } \\
\text { Diharapkan }\end{array}$ & $\begin{array}{c}\text { Hasil } \\
\text { Pengujian }\end{array}$ \\
\hline Shift siang & $\begin{array}{l}\text { Menampilkan deteksi } \\
\text { lokasi perangkat }\end{array}$ & sesuai \\
\hline Shift malam & $\begin{array}{l}\text { Menampilkan deteksi } \\
\text { lokasi perangkat }\end{array}$ & sesuai \\
\hline
\end{tabular}

Mulai lembur

Menampilkan deteks lokasi perangkat

Selesai

lembur

Menampilkan deteksi

lokasi perangkat

sesuai

sesuai

\section{Tanggal izin}

Detail alasan izin

Menampilkan detail
alasan izin
tanggal dan detail
alasan izin terkirim

sesuai sesuai

di dalam klinik

di luar klinik
Secara garis besar, Tabel 1 menunjukan hasil pengujian fungsionalitas dari sistem presensi ini berjalan dengan baik. Mulai dari login, kemudian menu utama, dilanjutkan dengan menu jenis presensi, sampai ke pendeteksian lokasi dari perangkat yang digunakan.

Sedangkan pada pengujian dengan menggunakan kuisioner atau metode User Acceptance, pegawai dari klinik pratama di kota Jember diberikan pertanyaan yang berkaitan dengan sistem presensi. Dari keseluruhan pegawai didapatkan 65 respon dari pegawai.

Tabel 2 menunjukan data pengujian dan hasilnya. Hasil dari pengujian aplikasi terlihat kalau hampir seluruh aspek yang menjadi penilaian dalam pengujian sistem bernilai rata-rata di atas 4.5, tepatnya 4.63. Namun yang masih perlu menjadi perbaikan dari sistem ini adalah pada aspek pengujian kecepatan respon yang masih di 
Tabel 2. Hasil Pengujian dengan Kuisioner Sederhana

\begin{tabular}{lccccccc}
\hline \multirow{2}{*}{ Aspek } & \multicolumn{7}{c}{ Nilai } \\
\cline { 2 - 8 } & $\begin{array}{c}\text { Sangat } \\
\text { Baik (5) }\end{array}$ & $\begin{array}{c}\text { Baik } \\
(4)\end{array}$ & $\begin{array}{c}\text { Normal } \\
(3)\end{array}$ & $\begin{array}{c}\text { Buruk } \\
(2)\end{array}$ & $\begin{array}{c}\text { Sangat } \\
\text { Buruk (1) }\end{array}$ & Jumlah & $\begin{array}{c}\text { Rata- } \\
\text { rata }\end{array}$ \\
\hline Konsep aplikasi & 46 & 13 & 6 & 0 & 0 & 65 & 4.62 \\
Kegunaan aplikasi & 52 & 8 & 5 & 0 & 0 & 65 & 4.72 \\
Model bisnis aplikasi & 55 & 9 & 1 & 0 & 0 & 65 & 4.83 \\
Tingkat akurasi aplikasi & 48 & 10 & 5 & 2 & 0 & 65 & 4.60 \\
$\begin{array}{l}\text { Kecepatan respon aplikasi } \\
\text { Keramahan penggunaan }\end{array}$ & 40 & 12 & 8 & 5 & 0 & 65 & 4.34 \\
aplikasi & 50 & 7 & 8 & 0 & 0 & 65 & 4.65 \\
\hline
\end{tabular}

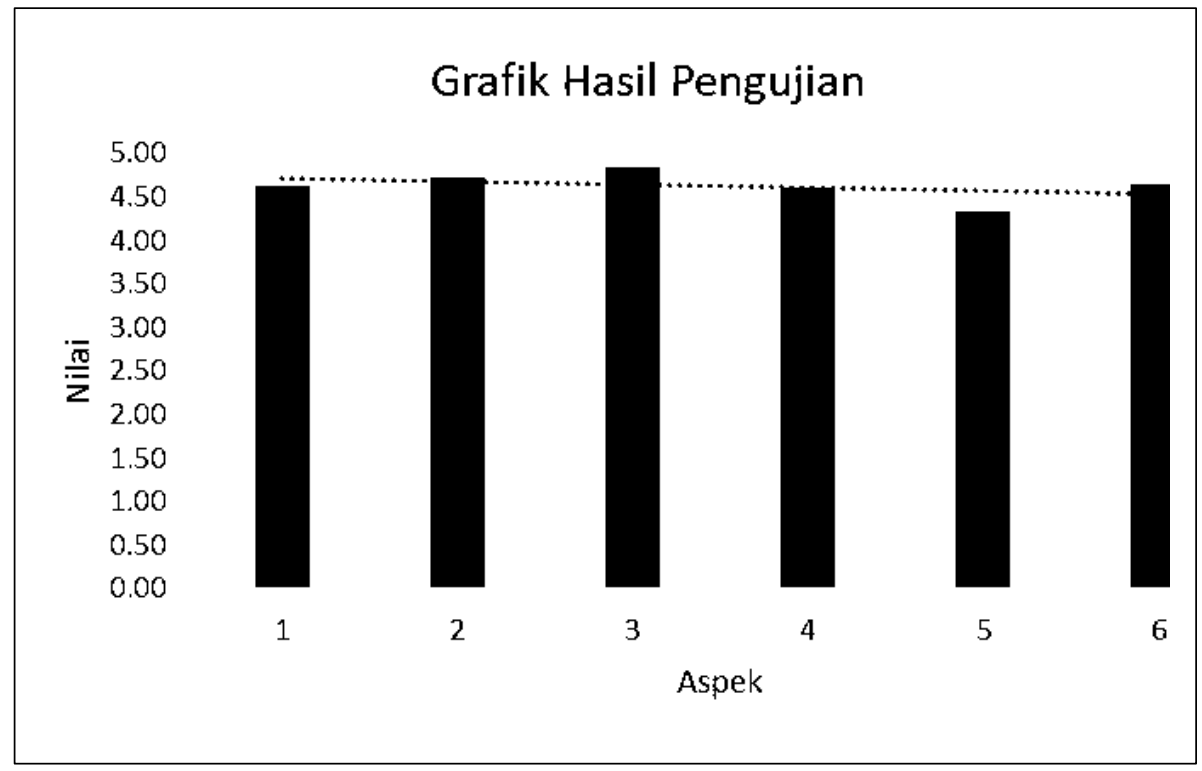

Gambar 7. Grafik Hasil Pengujian

\section{SIMPULAN}

Dari hasil dan pembahasan sebelumnya dapat disimpulkan bahwa sistem presensi berbasis mobile dengan memanfaatkan sensor GPS ini dapat diterapkan dengan baik pada bidang kesehatan, khususnya pada salah satu klinik pratama di kota Jember. Hasil pengujian yang menunjukan penerapan sistem ini berjalan dengan baik adalah pengujian fungsionalitas dengan metode Black bos. Dengan jumlah pegawai sebanyak 75 orang, sistem presensi ini dapat berjalan dengan baik. Namun dari hasil pengujian yang dilakukan, sistem presensi ini masih memiliki kekurangan pada aspek kecepatan respon. Dimana nilai untuk aspek tersebut masih di bawah rata- rata, yaitu 4.34. Secara keseluruhan ratarata nilai pengujian yang diperoleh adalah 4.63 .

Sistem presensi ini masih membutuhkan pengujian lain, untuk pengembangan versi dan peningkatan fiturnya. Pengujian lain tersebut dapat berupa pengujian User Interface. Sebagai contoh pada hasil pengujian tahap awal ini, pada aspek pengujian kecepatan respon didapatkan hasil yang masih di bawah nilai rata-rata. Sehingga dibutuhkan peningkatan kecepatan respon dari sistem presensi ini untuk versi berikutnya.

\section{REFERENSI}


[1] J. Christian and $\mathrm{H}$. Nasrullah, "Pemanfaatan Radio Frequency Identification (RFID) untuk Sistem Absensi Pegawai," Budi Luhur Information Technology, vol. 10, no. 1, 2013.

[2] Aris, I. Mubarak, W. Yuliardi, A. Ramadhan and A. Permana, "Desain Aplikasi Sistem Informasi Absensi Karyawan Dengan Radio Frequency Identification (RFID) Pada PT. Skyputra Pancasurya," Seminar Nasional Teknologi Informasi dan Multimedia, vol. 3, no. 1, pp. 4.6-1, 2015.

[3] J. F. DiMarzio, Beginning Android $®$ Programming with Android Studio, Indianapolis: John Wiley \& Sons, Inc., 2017.

[4] K. Rosyadi, Otomatisasi Presensi Menggunakan Global Positioning System (GPS), Malang: Skripsi Universitas Islam Negeri Maulana Malik Ibrahim, 2015.

[5] A. S. Syafawi, Sistem Presensi Online Berbasis Lokasi Studi Kasus Dosen DPK Fakultas Teknologi Industri Universitas Islam Indonesia, Yogyakarta: Skripsi, Universitas Islam Indonesia, 2017.

[6] R. M. Akbar and N. Prabowo, "Aplikasi Absensi Menggunakan Metode Lock GPS Dengan Android Di PT. PLN (Persero) App Malang Basecamp Mojokerto," Majapahit Techno, vol. V, no. 2, pp. 55-63, 2015.

[7] R. N. Rosso, Sistem Presensi Menggunakan Global Positioning System Berbasis Android, Semarang:
Skripsi, Universitas STIKUBANK (UNISBANK), 2017.

[8] R. Ayuninghemi and E. Mulyadi, "Evaluative Study of Clinical Management Information System with COBIT 4.1 Approach in Dokterku Taman Gading Jember Clinic," Proceeding of the 1st International Conference on Food and Agriculture, pp. 709-715, 2018.

[9] R. Saiful, Filosofi Agile dan Panduan Scrum, Jakarta: Leanpub, 2016.

[10] S. Nidhra and J. Dondeti, "Black Box And White Box Testing Techniques - A Literature Review," International Journal of Embedded Sustem and Applications (IJESA), vol. II, no. 2, pp. 29-50, 2012.

[11] G. Indrawan, G. T. Heriawan, A. I. I. Paramitha, I. G. Wiryawan, M. T. Sastradi and K. A. Sucahyana, "SIsKA: Mobile Based Academic Progress Information System," in 2nd International Conference on Innovative Research Across Disciplines (ICIRAD 2017), Bali, 2018. 